\title{
Reach for your cell phone at your own risk: The cognitive costs of media choice for breaks
}

\author{
SANGHOON KANG and TERRI R. KURTZBERG*
}

Rutgers Business School, Rutgers University, Piscataway, NJ, USA

(Received: November 7, 2018; revised manuscript received: March 25, 2019; accepted: April 7, 2019)

\begin{abstract}
Introduction: Since there is steady increase in cell phone addiction, the act of reaching for a phone between tasks, or even mid-task, is becoming more commonplace, without a true understanding about the potential cognitive costs of taking a break in this way as opposed to taking a break through another medium. Methods: This experimental study included 414 participants who completed a cognitively demanding task (solving anagrams) either on paper or on a computer screen. Participants in three of four randomly assigned conditions engaged in a break task (selecting items for a hypothetical shopping list) either on a cell phone, a larger computer screen, or on a paper in the middle of the task. The fourth condition had participants engaging in both halves of the cognitive task with no break. Results: The results show that using cell phone for a break did not allow brain to recharge as effectively as the other types of breaks, both in terms of being able to perform quickly and efficiently in the second half of the task (how long it took to complete), and in terms of performance (how many anagrams were successfully solved in the second half). Discussion and conclusions: As people are increasingly addicted to their cell phones, it is important to know the unintended costs associated with reaching for this device every spare minute. Although people may assume that it is not different from any other kind of interaction or break, this study shows that the phone might be more cognitively taxing than expected.
\end{abstract}

Keywords: cell phone addiction, breaks, cognitive resources

\section{INTRODUCTION}

Cell phone addiction is common in today's world (Roberts, Yaya, \& Manolis, 2014), leading to a host of potential complications, including poor sleep, depression, and anxiety (Demirci, Akgönül, \& Akpinar, 2015). Not only do the vast majority of adults own a cell phone (upward of $85 \%$ ), but they increasingly reach for their phones during every inbetween minute in their lives (De-Sola Gutiérrez, Rodríguez de Fonseca, \& Rubio, 2016; Forgays, Hyman, \& Schreiber, 2014) - whether it be first thing in the morning, while waiting on line, or while taking a break in the middle of another task. It is in this last area where this study aims to make a contribution, by addressing the cognitive consequences of reaching for a cell phone in the middle of a demanding task. This practice is relatively new to our society and as-yet-unproven as a cognitively effective break. Although the costs of cell phone addiction are becoming better understood as a drain on our sleep and positive emotions, there is still a need to understand the effects on our cognitive capacities.

Human brains are not built for sustained attention and hence people must learn to work efficiently within their cognitive limits. One way that people help to protect their cognitive resources from becoming exhausted is to take periodic breaks from tasks that require focused attention. A break is the act of temporarily halting and disengaging within or between tasks. Based on the effort-recovery model
(Meijman \& Mulder, 1998), breaks offer a good chance for individuals to recover cognitive power in order to optimize one's performance in the subsequent work (Hunter \& Wu, 2016). In longer tasks, breaks can also serve to refresh interest in the topic. For example, even though most people resist television advertisements, it turns out that people enjoy shows more when they are presented with these ads, since this can reduce the cognitive burnout of watching the show continuously, allow the brain to think about the show, and even build intrigue for the plot (Nelson, Meyvis, \& Galak, 2009).

The idea that breaks can serve a useful purpose is relatively intuitive, and research has begun to explore the content of various breaks and their relative restorative abilities (Trougakos, Beal, Green, \& Weiss, 2008). However, little is known about the form that a break takes. Thus, this study investigates whether the type of medium used during breaks (cell phone, paper, or computer-based) accelerates or decelerates cognitive exhaustion and measures subsequent cognitive ability to perform better in later tasks. Research has recognized the habit of being online to take a break at work (Kim et al., 2014), and has noted that this kind of break can indeed serve as restorative. The possible

* Corresponding author: Terri R. Kurtzberg; Rutgers Business School, Rutgers University, 100 Rockafeller Road, Piscataway, NJ 08854, USA; Phone: +1 848445 4458; Fax: +1 732445 6987; E-mail: tk@business.rutgers.edu

This is an open-access article distributed under the terms of the Creative Commons Attribution-NonCommercial 4.0 International License, which permits unrestricted use, distribution, and reproduction in any medium for non-commercial purposes, provided the original author and source are credited, a link to the CC License is provided, and changes - if any - are indicated. 
difference between using a cell phone and using a computer has not been examined; however, based on the different ways that we interact with these different devices, they may show their uniqueness in our response to breaks on one versus the other.

We predict that using cell phones in particular will be detrimental to further cognitive tasks because based on the addictive nature of cell phone use for people, extra cognitive resources are dedicated to interacting with the phone every time it is in use. Although screen-based tasks have been shown to be cognitively tiring overall (Gajendran, Loewenstein, \& Choi, 2013), we argue that cell phones will be yet more draining than would a computer screen because of the large number of addictive tasks readily engaged in, further distracting the mind even if those tasks are not currently occurring. It is here where this paper aims to contribute, by exploring a potential consequence of the addiction-fueled deeper cognitive attachment that people have with their cell phones than they do with other devices.

\section{Breaks and cognitive power}

In one sense, breaks are factors that obstruct the flow of work, which could thus detrimentally affect the efficiency and productivity levels of employees when they are engaged in simple and routine tasks (Ciulla, 2000; Perlow, 1999). Since taking a break is a type of interruption, the progress of a task to be completed declines and it becomes difficult to regain optimal engagement (known as "flow") again upon return (Csikszentmihalyi \& Csikszentmihalyi, 1992). Studies have shown that workers often do not immediately return to their original task after an interruption (Mark, 2015). They typically engage in two other tasks (on average) in between the interruption and the return to the original task. Even if breaks are taken between tasks, they could lead to the risk of losing the mind's focus on thinking and producing.

Yet another, more prominent, perspective maintains that breaks can serve positive ends as an incubation period that alleviates individuals' depletion level and leads to improved performance (Hunter \& Wu, 2016; Jett \& George, 2003), especially as work becomes more complex in nature. Indeed, even brief breaks to work on a separate task have been shown to diminish depletion and improve performance (Ariga \& Lleras, 2011). Breaks are especially helpful when one can choose the moment to disengage, as opposed to being interrupted, as this can help minimize the divided attention that results when one is, intentionally or unintentionally, maintaining thoughts about both tasks at once (Leroy, 2009; Leroy \& Schmidt, 2016). At their best, breaks help the mind to relax, allow emotional energy to recharge (Trougakos et al., 2008), and reinvigorate the memory system by storing what has already been done to free up more cognitive power for the next phase (Hunter \& Wu, 2016).

\section{Cell phones and cognitive engagement}

Research has begun to suggest that cell phone use is cognitively different from other kinds of engagement (Wilmer, Sherman, \& Chein, 2017). Cell phone addiction has been increasingly documented, in part based on the capacity to get "hooked" on reinforcing behaviors through this medium (such as receiving new messages), along with an observed loss of control despite its negative consequences or use in dangerous situations (De-Sola Gutiérrez et al., 2016). In addition, especially for young people for whom life has almost always included a cell phone as a primary tool of interaction and presentation, these devices have become a part of their entire identity and something that they cannot imagine life without (Roberts et al., 2014). In fact, several people of all ages are so connected with their phones at this point that it has become common to experience "phantom vibration syndrome" whereby one may mistakenly imagine that a phone has sent a message alert (Drouin, Kaiser, \& Miller, 2012). Because of this, even the mere presence of one's cell phone within view has been shown to be distracting, as the brain immediately thinks about what messages it might contain (Ward, Duke, Gneezy, $\&$ Bos, 2017). In brief, people get both cognitively and emotionally "lost" in their phones more often than they do in other devices or other types of breaks.

Theoretical work on the topic of interaction with digital technology has emerged through the Modality, Agency, Interactivity, and Navigability (MAIN model; Sundar, 2008). Of greatest relevance to this paper is the concept of modality, which refers to the structural medium itself and the associations and heuristics triggered because of these features. For example, the theory explains how new and flashy technologies might trigger the "coolness heuristic," whereas technologies that have the capability to constantly interrupt us might trigger the "intrusiveness heuristic" (Sundar, 2008, p. 82), each of which might change the way we interact with a particular type of technology and how we treat the information that we get from it.

Cell phones seem to activate a "keeping up with things" heuristic by triggering the deep-seated need to check in on the ongoing information flows and interactions that happen on that device. This need to constantly keep in touch helps drive the addictions that we see occurring. We argue that looking at one's cell phone will create just such a psychological need to check in with other interactions, and will thus be more distracting than other types of technological devices. Note that while these interactions are primarily social in nature for many people, there could also be other engaging and addictive activities, such as gaming or web searches or photos, which could lead to the same effects.

Research has shown that even seeing a message notification on one's cell phone is as cognitively distracting as is stopping and checking the message (Stothart, Mitchum, \& Yehnert, 2015), likely because it has created an open-ended question that the mind needs to be answered, similar to the Zeigarnik effect in which the mind dwells on unfinished business (Zeigarnik, 1938). This is related to the issue of attention residue (Leroy, 2009), which is the phenomenon that occurs when trying to switch between one task and another in which the mind is still processing thoughts about the first task while trying to engage with a second task. In the case of cell phone use, the addictive nature makes this problem of attention residue more likely; people seem to have half a mind on the phone at all times, and logically made worse by getting to interact with it for a moment during a break. 
For these reasons, we expect the special case of taking a break from a task using a cell phone to be more cognitively taxing than taking other kinds of breaks, even if the break task done on the cell phone is itself not related to personal messages or social interaction of any kind. In other words, we expect there to be a psychological and cognitive spillover effect from the activities most commonly (and most engagingly) done over cell phones to other tasks that are attempted through that medium. Just as the mere presence of a phone (even one not in use) during a conversation can limit disclosure and trust (Misra, Cheng, Genevie, \& Yuan, 2016; Przybylski \& Weinstein, 2013), we expect the level of subsequent cognitive ability to be lower when people use a cell phone for a break than when taken in other ways.

Hypothesis 1a: Participants who use cell phones to take a break in the middle of a demanding cognitive task will show higher levels of cognitive depletion than will participants who engage in other types of breaks.

Hypothesis $1 \mathrm{~b}$ : Participants who use cell phones to take a break in the middle of a demanding cognitive task will show lower task performance in the second half of the task than will participants who engage in other types of breaks.

\section{METHODS}

\section{Participants and study design}

Participants were 414 undergraduate students who received course credit for their participation and were randomly assigned to conditions. They were drawn from a population, containing $56 \%$ male and $44 \%$ female and had an average age of 22 years. In terms of ethnicity, the population was $22 \%$ White, $30 \%$ Asian, 13\% Black, 31\% Hispanic, and 4\% other. The experimental design compared breaks taken on a cell phone with breaks taken using other media (paper-based and on a full computer screen) in the middle of a cognitively demanding task. The medium of the main task was counterbalanced as well (paper-based and computer-based), and a no-break condition was included as a control.

\section{Procedure}

Participants first received instructions on how to solve anagram tasks (a set of jumbled letters that can be rearranged to form one or more English words), a task used in previous research (Park, Glaser, \& Knowles, 2008; Shah, Higgins, \& Friedman, 1998) as something cognitively difficult but solvable. After seeing a practiced anagram with a provided solution, the first half of the task presented 10 anagrams. This was followed by instructions on a break task to complete (in all but the no-break conditions), and finally the second set of 10 anagrams was provided as the critical task (numbered as 11-20 to maintain the continuity of the original task). To avoid excessive cognitive burnout on the first phase (from Park et al., 2008), and subsequent low motivation to complete the rest of the task, we opted to make 4 of the 10 anagrams in this first phase significantly easier than the rest (i.e., they contained only four letters instead of five, as did the remaining six anagrams). The second phase was composed of 10 difficult anagrams (from the study of Shah et al., 1998; see Appendix for both complete sets).

Participants either solved the anagrams via computer screen, on paper, or on their own personal cell phones. The two electronic conditions (cell phone and computer) utilized a link to a webpage, which contained the entire experiment, so that there was no concern about participants' potential hesitation to download anything to a personal device. Page breaks within the task were standardized, so that, regardless of the medium used, all participants needed to click forward to the next page in equivalent places. Participants could skip an anagram if needed and move on to the next one, could go back to continue to work on any of the anagrams previously seen in that section, or could enter more than one answer for a single string of letters (e.g., "eitm" could be solved as "time," "mite," or "item"). The amount of time that they spent on the final set of 10 anagrams was recorded.

In the break task, participants chose three items to buy within a specific budget from a store (using either a paper version of a store's advertised sales for the week or online platform). This task was chosen because it could realistically be performed via either a paper or an online format, was wholly unrelated to the focal task, and was common enough to be a true-to-life break. Participants either typed or wrote the reasons why they selected the items in a sentence or two, to ensure attention to this task. Participants in the no-break condition proceeded to work immediately on the second set of challenging anagrams.

\section{Ethics}

This study was approved by the Institutional Review Board of Rutgers University which the participants attended. All subjects were informed about the study and all provided informed consent, and all were over the age of 18 .

\section{Dependent variables}

Cognitive depletion. The amount of time that participants spent working on the second set of anagrams was measured as a proxy for cognitive depletion. This is the most common and standard way to estimate the level of depletion of cognitive resources (e.g., Muraven, Tice, \& Baumeister, 1998; Wan \& Sternthal, 2008), as it is assumed that more time participants spend trying to come up with solutions for each difficult anagram, the greater the amount of their cognitive depletion.

Task performance. As participants dealt with difficult anagrams, not unsolvable ones, task performance was measured by counting the number of correct solutions each participant came up with in the second half of the task.

\section{Statistical analyses}

To analyze the differences between break conditions (cell phone break, paper break, computer break, or no break), analysis of variance (ANOVA) was used with both participants' cognitive depletion level and subsequent task performance level in the second half of the task (after the break) 
as dependent variables. To ensure that baseline performance was not overly influencing the findings, performance and depletion in the first half of the task was used as a control variable in all models. Eta-squared statistics were calculated to examine effect sizes or the percentage of the overall variance explained in the model by these variables. The rule of thumb is that an eta-squared of 0.01 refers to a small effect size, 0.06 refers to a medium effect size, and 0.14 or larger refers to large effect sizes (Cohen, 1988; Miles \& Shevlin, 2001).

\section{RESULTS}

Before exploring the hypothesized effects, we first compared the two types of media used for the main task. In terms of cognitive depletion, both those who took a break in the middle of a paper-based task and those who took a break in the middle of a computer-based task took approximately the same amount of time to complete the second half of the task $(F=0.311, d f=223, p>.5)$. Similarly, with respect to task performance, both those who took a break in the middle of a paper-based task and those who took a break in the middle of a computer-based task solved approximately the same number of problems in the second half of the task $(F=0.057, d f=223, \quad p>.5)$. Similarly, those in the no-break condition on paper were also statistically indistinguishable from those in the no-break condition on the computer for cognitive depletion $(F=1.31, d f=82$, $p>.1)$ and for subsequent task performance $(F=0.24$, $d f=82, p>.05)$. This is in contrast with the findings of Gajendran et al. (2013), who found that screen-based tasks in general were more depleting. Thus, we were able to collapse the main-task conditions (paper and computer) and only compare groups based on break-task medium.

Hypotheses $1 a$ and $1 b$ predicted that participants who used their cell phones for the break task would have higher levels of cognitive depletion and lower levels of subsequent task performance than those who took other kinds of breaks (see Tables 1 and 2 for descriptive statistics for all study conditions).

Hypothesis 1 a expected that participants in the cell phone break conditions would lead to higher levels of cognitive depletion than other break conditions. The overall ANOVA testing cell phone breaks versus other types of breaks was significant $\left(F=20.764, p<.001, d f=326, \eta^{2}=0.06\right)$, demonstrating that there were meaningful cognitive depletion differences between cell phone breaks $(M=330.49$, $S D=80.42)$ and other types of breaks $(M=277.12$, $S D=97.19$ ) with a medium effect size. In other words, those in the cell phone break condition took longer in the second half of the task than those who took other breaks. Thus, Hypothesis la was supported. In further post-hoc Tukey's test analyses (see Table 3), it is interesting to note that there was no statistical difference between those who took cell phone breaks and those who took no break at all $(M=355.68, S D=73.90 ; F=2.448, d f=185, p>.1)$, suggesting that the cognitive recharging that happened in the paper or computer break conditions did not happen in the cell phone condition.

Table 1. Descriptive table for cognitive depletion

\begin{tabular}{|c|c|c|c|}
\hline Condition & Cognitive depletion & Condition (overall) & Cognitive depletion \\
\hline $\begin{array}{l}\text { Task: paper } \\
\text { Break: cell } \\
N=34 \\
\text { Task: computer } \\
\text { Break: cell } \\
N=69\end{array}$ & $\begin{array}{c}M=394.46 \\
S D=66.59 \\
{[371.22,417.69]} \\
M=298.97 \\
S D=67.05 \\
{[282.86,315.08]}\end{array}$ & Cell phone breaks & $\begin{array}{c}M=330.49 \\
S D=80.42 \\
{[314.77,346.21]}\end{array}$ \\
\hline $\begin{array}{l}\text { Task: paper } \\
\text { Break: none } \\
N=52 \\
\text { Task: computer } \\
\text { Break: none } \\
N=33\end{array}$ & $\begin{array}{c}M=363.56 \\
S D=73.12 \\
{[343.20,383.91]} \\
M=343.27 \\
S D=74.55 \\
{[317.93,369.70]}\end{array}$ & No break & $\begin{array}{c}M=355.68 \\
S D=73.90 \\
{[339.74,371.62]}\end{array}$ \\
\hline $\begin{array}{l}\text { Task: paper } \\
\text { Break: paper } \\
N=56 \\
\text { Task: computer } \\
\text { Break: paper } \\
N=55\end{array}$ & $\begin{array}{c}M=252.12 \\
S D=74.69 \\
{[232.11,272.12]} \\
M=299.53 \\
S D=96.80 \\
{[273.36,325.70]}\end{array}$ & Paper breaks & $\begin{array}{c}M=275.61 \\
S D=89.20 \\
{[258.83,292.39]}\end{array}$ \\
\hline $\begin{array}{l}\text { Task: paper } \\
\text { Break: computer } \\
N=60 \\
\text { Task: computer } \\
\text { Break: computer } \\
N=55\end{array}$ & $\begin{array}{c}M=331.36 \\
S D=91.00 \\
{[307.95,354.87]} \\
M=221.02 \\
S D=87.31 \\
{[197.42,244.62]}\end{array}$ & Computer breaks & $\begin{array}{c}M=278.59 \\
S D=104.69 \\
{[259.25,297.93]}\end{array}$ \\
\hline
\end{tabular}

Note. $N$ : number of participants; $M$ : mean; $S D$ : standard deviation [ $95 \%$ confidence interval]. 
Cell phone breaks

Table 2. Descriptive table for subsequent task performance

\begin{tabular}{|c|c|c|c|}
\hline Condition & Subsequent task performance & Condition (overall) & Subsequent task performance \\
\hline $\begin{array}{l}\text { Task: paper } \\
\text { Break: cell } \\
N=34 \\
\text { Task: computer } \\
\text { Break: cell } \\
N=69\end{array}$ & $\begin{array}{c}M=6.56 \\
S D=1.64 \\
{[5.99,7.13]} \\
M=6.29 \\
S D=1.38 \\
{[5.96,6.62]}\end{array}$ & Cell phone breaks & $\begin{array}{c}M=6.38 \\
S D=1.47 \\
{[6.09,6.67]}\end{array}$ \\
\hline $\begin{array}{l}\text { Task: paper } \\
\text { Break: none } \\
N=52 \\
\text { Task: computer } \\
\text { Break: none } \\
N=33\end{array}$ & $\begin{array}{c}M=5.48 \\
S D=1.81 \\
{[4.98,5.98]} \\
M=5.06 \\
S D=1.48 \\
{[4.54,5.58]}\end{array}$ & No break & $\begin{array}{c}M=5.32 \\
S D=1.69 \\
{[4.95,5.68]}\end{array}$ \\
\hline $\begin{array}{l}\text { Task: paper } \\
\text { Break: paper } \\
N=56 \\
\text { Task: computer } \\
\text { Break: paper } \\
N=55\end{array}$ & $\begin{array}{c}M=8.66 \\
S D=1.57 \\
{[8.32,9.00]} \\
M=7.58 \\
S D=1.20 \\
[7.26,7.91)]\end{array}$ & Paper breaks & $\begin{array}{c}M=8.13 \\
S D=1.34 \\
{[7.87,8.38]}\end{array}$ \\
\hline $\begin{array}{l}\text { Task: paper } \\
\text { Break: computer } \\
N=60 \\
\text { Task: computer } \\
\text { Break: computer } \\
N=55\end{array}$ & $\begin{array}{c}M=7.55 \\
S D=1.57 \\
{[7.15,7.95]} \\
M=8.76 \\
S D=1.52 \\
{[8.35,9.17]}\end{array}$ & Computer breaks & $\begin{array}{c}M=8.13 \\
S D=1.65 \\
{[7.83,8.44]}\end{array}$ \\
\hline
\end{tabular}

Note. $N$ : number of participants; $M$ : mean; $S D$ : standard deviation [ $95 \%$ confidence interval].

Table 3. Post-hoc Tukey's tests for cognitive depletion by condition

\begin{tabular}{lccc}
\hline & & Mean & \\
Condition A & Condition B & difference & $S E$ \\
\hline Cell phone break & Paper break & $54.883^{* * *}$ & 12.168 \\
& Computer break & $51.903 * * *$ & 12.066 \\
& No break & -25.189 & 13.033 \\
Paper break & Computer break & -2.980 & 11.834 \\
& No break & $80.073 * * *$ & 12.819 \\
Computer break & No break & $77.092^{* * *}$ & 12.722 \\
\hline
\end{tabular}

Note. SE: standard error.

$* * * p<.001$.

Hypothesis $1 b$ predicted that participants in the cell phone break condition would have lower subsequent task performance than other break conditions. The overall ANOVA testing was significant $(F=129.886, d f=326$, $\left.p<.001, \eta^{2}=0.285\right)$, demonstrating that there were meaningful subsequent task performance differences between cell phone breaks $(M=6.38, S D=1.47)$ and other types of breaks $(M=8.13, S D=1.50)$, with a quite large effect size. In other words, those in the cell phone break condition solved fewer problems in the second half of the task as compared to those in any other break condition. Thus, Hypothesis $1 b$ was supported. In this case, however, the Tukey's comparison (Table 4) between the cell phone break and the no-break condition was significant, with those in the cell phone break condition $(M=6.38, S D=1.47)$ solving more anagrams in the second half of the task than those in
Table 4. Post-hoc Tukey's tests for subsequent task performance

\begin{tabular}{lccc}
\hline Condition A & Condition B & Mean difference & $S E$ \\
\hline Cell phone break & Paper break & $-1.747^{* * *}$ & 0.210 \\
& Computer break & $-1.752^{* * *}$ & 0.208 \\
& No break & $1.061^{* * *}$ & 0.225 \\
Paper break & Computer break & -0.004 & 0.204 \\
& No break & $2.808^{* * *}$ & 0.221 \\
Computer break & No break & $2.813^{* * *}$ & 0.220 \\
\hline
\end{tabular}

Note. SE: standard error.

$* * * p<.001$.

the no-break condition $(M=5.32, S D=1.69 ; F=24.961$, $\left.d f=185, p<.001, \eta^{2}=0.119\right)$, although fewer than those with any other type of break, with a medium effect size (see Figures 1 and 2).

\section{DISCUSSION}

In these results, an overall pattern appeared whereby those who stopped their tasks to take a break on their cell phones fared worse than any other type of break in terms of their subsequent performance, regardless of the main task medium used. Cell phone breaks resulted in the same levels of cognitive depletion as not taking any break at all. As our society increasingly grapples with cell phone addiction, with more and more use of these devices during free moments between (and even during) tasks, it is even significant to understand how these actions may negatively affect our cognitive skills. 


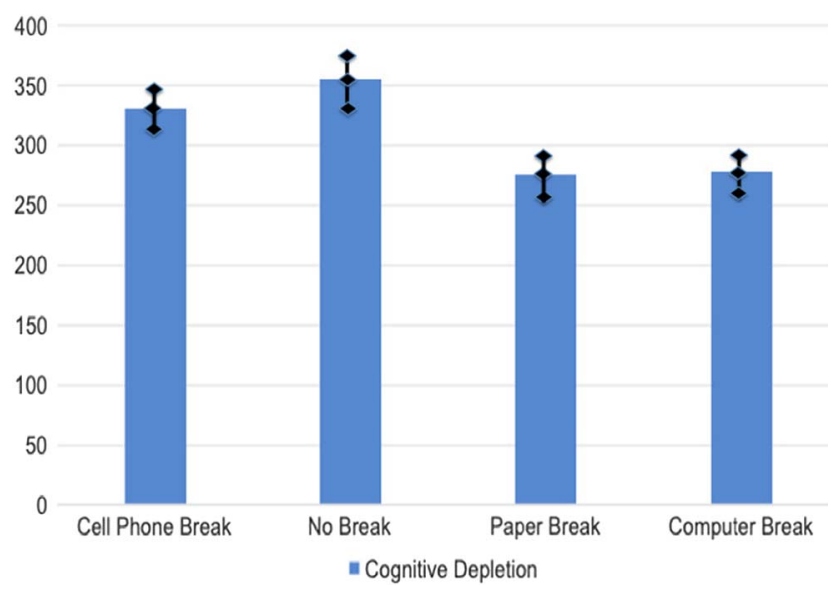

Figure 1. Effect of breaks on cognitive depletion in time in seconds (means with $95 \%$ confidence intervals shown)

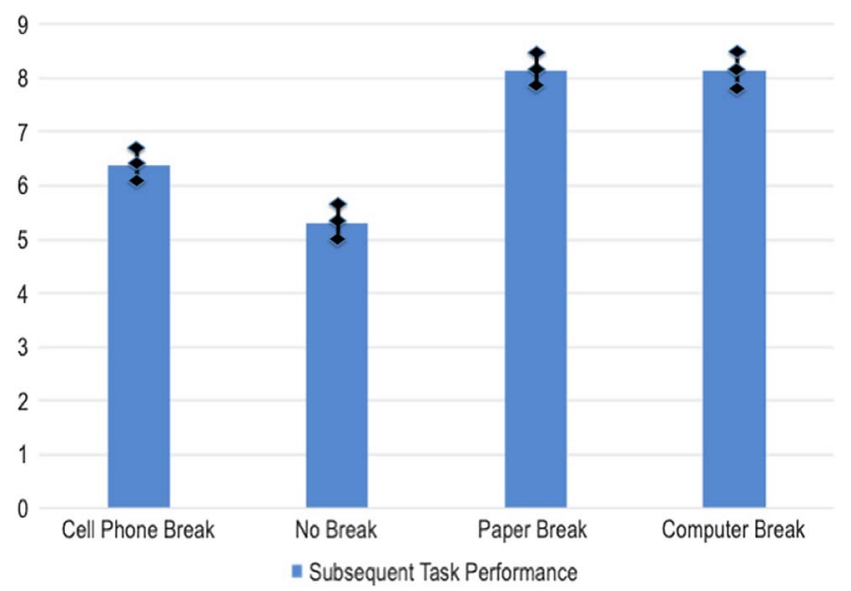

Figure 2. Effect of breaks on subsequent task performance in numbers of correct answers (means with 95\% confidence intervals shown)

Especially in a world filled with cognitive overload at every turn, pausing in the middle of tough tasks can allow one to better attack the next phase. However, our results showed that not all break media were identically able to provide this recharging effect, and the one that might be most appealing (especially to those addicted to cell phone use) may in fact be the worst choice. Indeed, in terms of task performance, if one reaches for a cell phone during a break, it seems to hinder future performance more than using either a computer screen or a paper-based task for the break instead.

It is particularly interesting that reaching for a cell phone and interacting with another screen-based medium (such as a computer) during a break produced such different results. This reinforces the idea that we may not engage with all screens in an identical fashion. Cell phones, because of their addictive nature and high levels of involvement in daily life, may now carry additional levels of magnetism and distraction that make it difficult to return focused attention to work tasks. This finding supports the developing theory that people are more cognitively and emotionally attached to their phones than they are to other devices, including other electronic tools such as computers. The prevalence of people interrupting a task to look at their phones makes this exploration important.

When it comes to cell phones, the prominent areas of concern are the alerts and notifications that can interrupt other work, conversations, and thought processes. It stands to reason that being interrupted mid-stream on a task or a conversation could force one to lose the thread of the original task more readily. However, in this experiment, the break was not an interruption per se, but was instead a planned and pre-announced part of the process. In addition, in this sense of timing, the break was identical across conditions and so the degree of interruption was held constant. Moreover, the cell phone seemed to serve as the least effective form of a break here studied, indicating that it is not just the matter of a cell phone being a more interruption-prone device that is cause for concern in its use as a break mechanism.

It is possible that the smaller screen size of the cell phones may have contributed to the different outcomes. The studies on screen size differences influencing people's behaviors and performance in other areas (e.g., Kim \& Sundar, 2016; Kurtzberg, Kang, \& Naquin, 2018) show, for example, that people may not interact in the same way through cell phones as through larger screens, and may even end up more cognitively depleted when they see objects through screens at an unfamiliar size (Reeves, Lang, Kim, \& Tatar, 1999), such as smaller than normal as viewed through a mobile phone screen. However, since the task used for the break was a shopping task, which is commonly executed by people of the college-student age group studied here, it does not seem likely that the small screen size is the main driver of the effect that we have observed here, although it might have contributed to the results. Further work is needed to tease apart the differences between size and effectiveness with respect to tasks completed on cell phones, as well as to explore whether a longer task or a longer break might show the same effects. Similarly, performing the main task on a cell phone might also have implications for how the various breaks function.

Furthermore, the nature of the experiment was to require all participants to perform the same task during the break such as shopping. That activity is likely to be more relaxing for some than for others, and research has shown that relaxation during breaks is a critical element of recharging cognitively (Bosch, Sonnentag, \& Pinck, 2018). Other individual-difference variables may also influence this phenomenon, such as the degree of self-efficacy that people feel toward their interactions with technology (Wu, Cheung, $\mathrm{Ku}$, \& Hung, 2013). However, the random assignment used in this experiment should ameliorate much of these types of individual-difference-based concerns. Future research can also explore whether other types of interactions via cell phone, such as checking and answering messages, would have the same or different effects on the ability to successfully return to work tasks.

\section{CONCLUSIONS}

These findings contribute to the growing body of work that explores the nuances of the cell phone addictions that many 
people currently live with. In this case, the question is whether taking a break with a cell phone in hand serves as a true mental break from actual work tasks, or whether looking at a phone might unintentionally add to the cognitive load of the mind instead of relieving it. The results show that breaks might be better spent without the cell phone, if the goal is to have restored cognitive ability for subsequent work tasks.

\section{Funding sources: None.}

Authors' contribution: Both authors contributed equally to this manuscript. They had full access to all data in the study and take responsibility for the integrity of the data and the accuracy of the data analysis.

Conflict of interest: The authors declare no conflict of interest.

\section{REFERENCES}

Ariga, A., \& Lleras, A. (2011). Brief and rare mental "breaks" keep you focused: Deactivation and reactivation of task goals preempt vigilance decrements. Cognition, 118(3), 439-443. doi:10.1016/j.cognition.2010.12.007

Bosch, C., Sonnentag, S., \& Pinck, A. (2018). What makes for a good break? A diary study on recovery experiences during lunch break. Journal of Occupational and Organizational Psychology, 91(1), 134-157. doi:10.1111/joop.12195

Ciulla, J. (2000). The working life: The promise and portrayal of modern work. New York, NY: Three River Press.

Cohen, J. (1988). Statistical power analysis for the behavioral sciences (2nd ed.). Hillsdale, NJ: Lawrence Erlbaum Associates.

Csikszentmihalyi, M., \& Csikszentmihalyi, I. S. (Eds.). (1992). Optimal experience: Psychological studies of flow in consciousness. New York, NY: Cambridge University Press.

De-Sola Gutiérrez, J., Rodríguez de Fonseca, F., \& Rubio, G. (2016). Cell-phone addiction: A review. Frontiers in Psychiatry, 7, 175-190. doi:10.3389/fpsyt.2016.00175

Demirci, K., Akgönül, M., \& Akpinar, A. (2015). Relationship of smartphone use severity with sleep quality, depression, and anxiety in university students. Journal of Behavioral Addictions, 4(2), 85-92. doi:10.1556/2006.4.2015.010

Drouin, M., Kaiser, D. H., \& Miller, D. A. (2012). Phantom vibrations among undergraduates: Prevalence and associated psychological characteristics. Computers in Human Behavior, 28(4), 1490-1496. doi:10.1016/j.chb.2012.03.013

Forgays, D., Hymna, I. E., \& Schreiber, J. (2014). Texting everywhere for everything: Gender and age differences in cell phone etiquette and use. Computers in Human Behavior, 31, 314-321. doi:10.1016/j.chb.2013.10.053

Gajendran, R. S., Loewenstein, J., \& Choi, H. (2013). Is email a brain drain? Communication media effects and depletion in negotiation tasks. Academy of Management Proceedings, 2013(1), 16770. doi:10.5465/ambpp.2013.16770abstract

Hunter, E., \& Wu, C. (2016). Give me a better break: Choosing workday break activities to maximize resource recovery.
Journal of Applied Psychology, 101(2), 302-311. doi:10.1037/ap10000045

Jett, Q. R., \& George, J. M. (2003). Work interrupted: A closer look at the role of interruptions in organizational life. Academy of Management Review, 28(3), 494-507. doi:10.5465/amr. 2003.10196791

Kim, K. J., \& Sundar, S. S. (2016). Mobile persuasion: Can screen size and presentation mode make a difference to trust? Human Communication Research, 42(1), 45-70. doi:10.1111/ hcre. 12064

Kim, S. D., Bologna, D. A., Furst-Holloway, S., Hollensbe, E. C., Masterson, S. S., \& Sprinkle, T. (2014). Taking a break via technology? Triggers, nature, and effects of "online" work breaks. Academy of Management Proceedings, 2014(1), 11891. doi:10.5465/ambpp.2014.9

Kurtzberg, T., Kang, S., \& Naquin, C. (2018). The effect of screen size and e-communication richness on negotiation performance. Group Decision and Negotiation, 27(4), 573-592. doi:10.1007/s10726-018-9574-x

Leroy, S. (2009). Why is it so hard to do my work? The challenge of attention residue when switching between work tasks. Organizational Behavior and Human Decision Processes, 109(2), 168-181. doi:10.1016/j.obhdp.2009.04.002

Leroy, S., \& Schmidt, A. M. (2016). The effect of regulatory focus on attention residue and performance during interruptions. Organizational Behavior and Human Decision Processes, 137, 218-235. doi:10.1016/j.obhdp.2016.07.006

Mark, G. (2015). Multitasking in the digital age. Synthesis Lectures on Human-Centered Informatics, 8(3), 1-113. doi:10.2200/ S00635ED1V01Y201503HCI029

Meijman, T. F., \& Mulder, G. (1998). Psychological aspects of workload. In P. J. D. Drenth \& H. Thierry (Eds.), Handbook of work and organizational psychology: Vol 2: Work psychology (2nd ed., pp. 5-33). Hove, UK: Psychology Press.

Miles, J., \& Shevlin, M. (2001). Applying regression and correlation: A guide for students and researchers. London, UK: Sage Publications.

Misra, S., Cheng, L., Genevie, J., \& Yuan, M. (2016). The iPhone effect: The quality of in-person social interactions in the presence of mobile devices. Environment and Behavior, 48(2), 275-298. doi:10.1177/0013916514539755

Muraven, M., Tice, D. M., \& Baumeister, R. F. (1998). Selfcontrol as a limited resource: Regulatory depletion patterns. Journal of Personality and Social Psychology, 74(3), 774-789. doi:10.1037/0022-3514.74.3.774

Nelson, L. D., Meyvis, T., \& Galak, J. (2009). Enhancing the television-viewing experience through commercial interruptions. Journal of Consumer Research, 36(2), 160-172. doi:10.1086/597030

Park, S. H., Glaser, J., \& Knowles, E. D. (2008). Implicit motivation to control prejudice moderates the effect of cognitive depletion on unintended discrimination. Social Cognition, 26(4), 401-419. doi:10.1521/soco.2008.26.4.401

Perlow, L. A. (1999). The time famine: Toward a sociology of work time. Administrative Science Quarterly, 44(1), 57-81. doi: $10.2307 / 2667031$

Przybylski, A. K., \& Weinstein, N. (2013). Can you connect with me now? How the presence of mobile communication technology influences face-to-face conversation quality. Journal of Social and Personal Relationships, 30(3), 237-246. doi:10.1177/0265407512453827 
Reeves, B., Lang, A., Kim, E., \& Tatar, D. (1999). The effects of screen size and message content on attention and arousal. Media Psychology, 1(1), 49-67. doi:10.1207/s1532785xmep0101_4

Roberts, J. A., Yaya, L. H. P., \& Manolis, C. (2014). The invisible addiction: Cell-phone activities and addiction among male and female college students. Journal of Behavioral Addictions, 3(4), 254-265. doi:10.1556/JBA.3.2014.015

Shah, J., Higgins, T., \& Friedman, R. S. (1998). Performance incentives and means: How regulatory focus influences goal attainment. Journal of Personality and Social Psychology, 74(2), 285-293. doi:10.1037/0022-3514.74.2.285

Sundar, S. S. (2008). The MAIN model: A heuristic approach to understanding technology effects on credibility. In M. Metzger \& A. Flanagin (Eds.), Digital media, youth, and credibility (pp. 73-100). Cambridge, MA: MIT Press.

Stothart, C., Mitchum, A., \& Yehnert, C. (2015). The attentional cost of receiving a cell phone notification. Journal of Experimental Psychology: Human Perception and Performance, 41, 893-897. doi:10.1037/xhp0000100

Trougakos, J., Beal, D., Green, S., \& Weiss, H. (2008). Making the break count: An episodic examination of recovery activities, emotional experiences, and positive affective displays.
Academy of Management Journal, 51(1), 131-146. doi:10.5465/amj.2008.30764063

Wan, E. W., \& Sternthal, B. (2008). Regulating the effects of depletion through monitoring. Personality and Social Psychology Bulletin, 34(1), 32-46. doi:10.1177/014616720 7306756

Ward, A. F., Duke, K., Gneezy, A., \& Bos, M. W. (2017). Brain drain: The mere presence of one's own smartphone reduces available cognitive capacity. Journal of the Association for Consumer Research, 2(2), 140-154. doi:10.1086/691462

Wilmer, H. H., Sherman, L. E., \& Chein, J. M. (2017). Smartphones and cognition: A review of research exploring the links between mobile technology habits and cognitive functioning. Frontiers in Psychology, 8, 605-621. doi:10.3389/ fpsyg.2017.00605

Wu, A. M., Cheung, V. I., Ku, L., \& Hung, E. P. (2013). Psychological risk factors of addiction to social networking sites among Chinese smartphone users. Journal of Behavioral Addictions, 2(3), 160-166. doi:10.1556/JBA.2.2013.006

Zeigarnik, B. (1938). On finished and unfinished tasks. In W. D. Ellis (Ed.), A source book of gestalt psychology (pp. 300-314). New York, NY: Harcourt, Brace, \& World. 
APPENDIX: DIFFICULT BUT SOLVABLE ANAGRAMS ADAPTED FROM PARK ET AL. (2008) AND SHAH ET AL. (1998)

(a) Park et al. (2008)

\begin{tabular}{ll}
\hline Set & \multicolumn{1}{c}{ Example } \\
\hline aste* $_{\text {dite* }}$ & east and seat \\
rcalel & Edit and tide \\
earinm & Recall and cellar \\
atcs* & marine, remain, and airmen \\
lpseta & cats, cast, and acts \\
edovet & Plates and staple \\
emat* & devote and vetoed \\
tocrse & team, mate, meat, and tame \\
pnsrtee & sector, escort, and corset \\
\hline
\end{tabular}

Note. *Randomly selected anagrams from the easy list of the paper to prevent participants from being demotivated.

(b) Shah et al. (1998)

\begin{tabular}{ll}
\hline Set & \multicolumn{1}{c}{ Example } \\
\hline $\begin{array}{c}\text { Practice } \\
\text { eachp } \\
\text { Experimental } \\
\text { nelmo } \\
\text { anetlm }\end{array}$ & Peach and cheap \\
ilesm & Melon and lemon \\
olspo & Mental and lament \\
leestc & smile, limes, miles, and slime \\
niedm & pools, spool, and loops \\
hrbot & select and elects \\
idfel & denim and mined \\
veerl & throb and broth \\
sdetre & filed and field \\
\hline
\end{tabular}

